Diabetologia 10, 415-420 (1974)

(C) by Springer-Verlag 1974

\title{
L-Leucine and L-Phenylalanine Induced Insulin Release and the Influence of D-Glucose
}

\section{Kinetic Studies with the Perfused Rat Pancreas}

\author{
R. Landgraf, M.M.C. Landgraf-Leurs and R. Hörl \\ II. Medical Clinic, University of Munich, Germany
}

Received: January 24, 1974, and in revised form: May 8, 1974

\begin{abstract}
Summary. The perfused pancreas was used for kinetic studies of leucine and phenylalanine induced insulin secretion. In a glucose-free medium, leucine stimulated insulin release over a wide range $(5-80 \mathrm{mM})$. Substimulatory levels of glucose $(3 \mathrm{mM})$ potentiated the leucine induced insulin release. At higher glucose concentrations $(20 \mathrm{mM})$, the rate of leucine-provoked insulin release was not further enhanced. Phenylalanine (5$80 \mathrm{mM}$ ) did not provoke significant insulin secretion, either in the presence or in the absence of $3 \mathrm{mM}$ glucose.
\end{abstract}

However a dose-dependent "off-effect" was observed up to $20 \mathrm{mM}$ phenylalanine. Insulin release due to glucose $(20 \mathrm{mM})$ was temporarily inhibited by phenylalanine. The different kinetics for both amino acids may indicate, that receptors are involved in triggering insulin release and that glucose seems to be an important modulator of the amino acid response.

Key words: Pancreas perfusion, insulin secretion, amino acids, glucose, membrane receptors.
Naturally occuring as well as synthetic, nonmetabolizable amino acids are insulin stimulators [1-4]. However amino acids differ markedly in their insulin releasing capacities both in vivo and in vitro [1, 5-7]. Investigations of the metabolism of certain amino acids suggested that amino acid induced insulin release is not due to the fact that they serve as fuels for the islets of Langerhans [9]. On the basis of transport studies it has been proposed that amino acids provoke insulin release by binding to specific receptors [2]. Using the isolated rat pancreas, we have investigated the dynamics of insulin secretion in response to leucine and phenylalanine at various concentrations and in different combinations with glucose. It is suggested that the results present further evidence for the importance of direct receptor sites in amino acid induced insulin release.

\section{Materials and Methods}

Material. All reagents were of analytical grade. Dextran (MW 60,000-80,000), purchased from Knoll AG, Ludwigshafen, Germany, was dialyzed against twice distilled water to remove traces of contaminating glucose. D-glucose, L-Leucine and L-phenylalanine were obtained from Merck AG, Darmstadt.

Methods. D-glucose in dialyzed dextran was measured by an enzymatic fluorometric assay [10]. Insulin in the perfusate was determined by the immunoassay of Hales and Randle [11], using human insulin as the standard. The insulin concentrations are therefore expressed as equivalents of human insulin. The radioimmunoassay was not affected by low or high concentrations of leucine or phenylalanine.

Male Sprague-Dawley rats, $150-300 \mathrm{~g}$ and fed ad libitum with Altromin ${ }^{\circledR}$ chow and water, were used as pancreas donors. After an overnight fast, the animals were injected intraperitoneally with atropine $(0.15$ $\mathrm{mg} / \mathrm{kg}$ body weight) and anesthetized with pentobarbital (55 mg/kg body weight). The pancreas, with the adjacent stomach, spleen and proximal part of the duodenum, was removed. The celiac axis and the portal vein were cannulated and the tissue was then placed in a perfusion apparatus at a temperature of $35-37^{\circ} \mathrm{C}$. The perfusion system used was a modification of that described by Sussman et al. [8]. The perfusate was not allowed to recycle.

The perfusion fluid consisted of: $\mathrm{NaCl}, 120 \mathrm{mM}$; $\mathrm{KCl}, 4.7 \mathrm{mM} ; \mathrm{MgSO}_{4}, 0.8 \mathrm{mM} ; \mathrm{CaCl}_{2}, 2.5 \mathrm{mM} ; \mathrm{KH}_{2} \mathrm{PO}_{4}$ $1.2 \mathrm{mM}$, and $\mathrm{NaHCO}_{3}, 25 \mathrm{mM}$. Dialyzed Dextran ( $8 \%$ ) was added to provide a colloid osmotic pressure comparable to that of plasma. The perfusate was prewarmed to $37^{\circ} \mathrm{C}$ and equilibrated with $\mathrm{O}_{2}: \mathrm{CO}_{2}$ $(95: 5)$ and finally adjusted with $\mathrm{HCl}$ to a $\mathrm{pH}$ of 7.4 . During a perfusion period of $10-20 \mathrm{~min}$ the flow rate was adjusted to $5 \mathrm{ml} / \mathrm{min}$ resulting in a perfusion pressure of $60-80 \mathrm{~mm} \mathrm{Hg}$ in the arterial cannula. At the end of this stabilization period three samples were taken as controls. At zero time the stimulatory period was started by switching a three-way valve from the control solution to the stimulatory perfusion fluid. A very small dead space in the connecting tubing at the arterial and venous side provided a rapid change, which was completed within seconds.

The effluent was sampled for seven seconds at time intervals indicated in the figures. After sampling the samples were stored frozen at $-20^{\circ} \mathrm{C}$ until used.

\section{Results}

The serretion kinetics shown in the following figures and represent mean curves with their standard errors. It has to be stressed that the individual insulin patterns of different animals are qualitatively reproducible, but vary with respect to the amounts of 
insulin secreted. The quantitative differences in insulin release to the same stimulus between different animals could not be related to the basal secretion rate of these animals. We therefore did not compute the relative insulin responses (increment in insulin release divided by the basal insulin secretion $\times 100)[12]$.

\section{Leucine-Induced Insulin Release}

a) Dose-dependent Insulin Secretion due to Leucine. In a glucose-free medium the secretory response to $5-80 \mathrm{mM}$ leucine was biphasic and dose-dependent (Fig. 1, 2). A linear relationship was observed between the leucine concentration up to $20 \mathrm{mM}$ and the initial

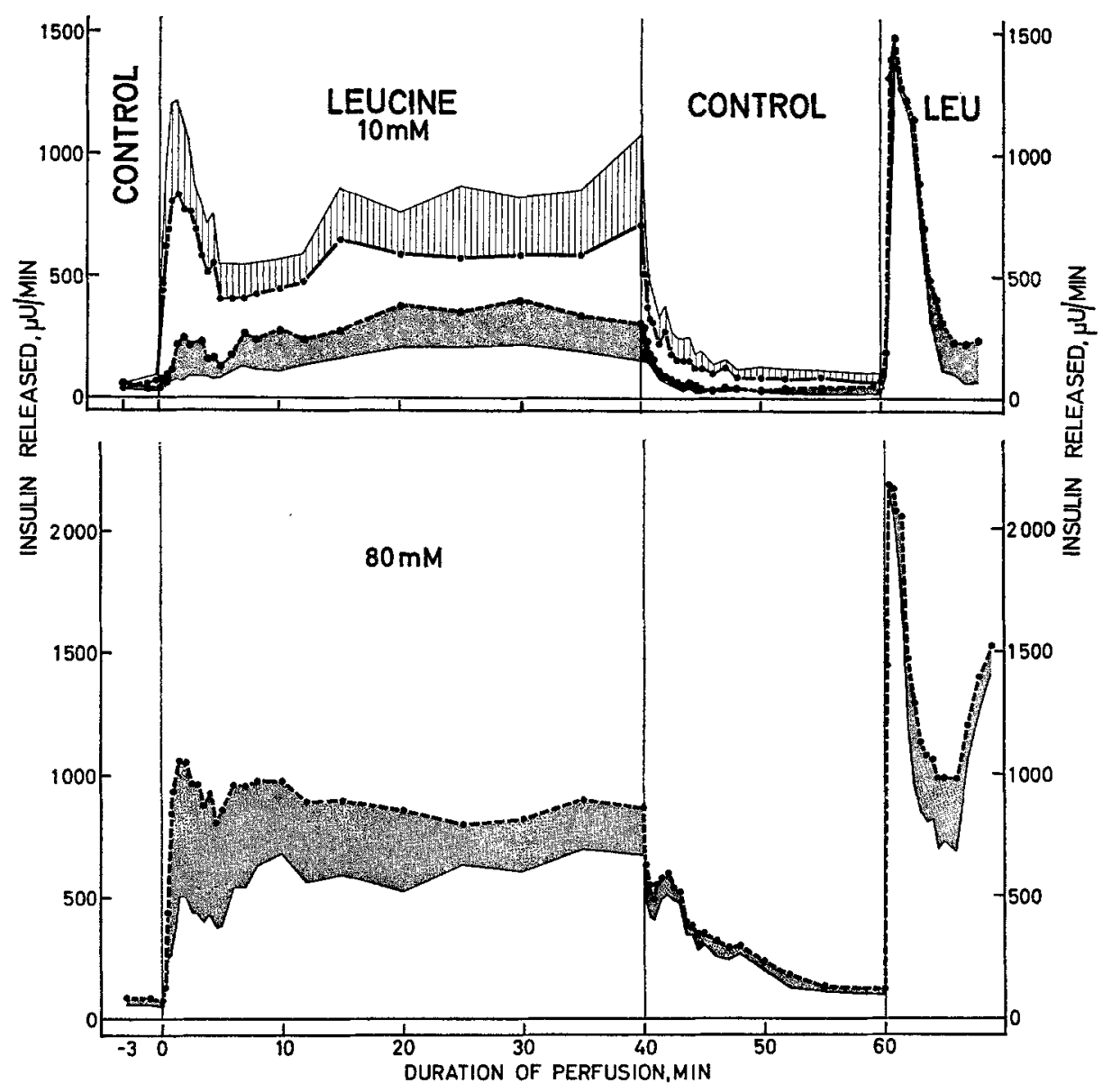

Fig. 1. Insulin secretory profiles induced by leucine in the presence (- - $)$ ) and absence (-.-.) of substimulatory levels of glucose $(3 \mathrm{mM})$. Mean values $\pm \mathrm{SEM}$ for $5(10 \mathrm{mM})$ and $3(80 \mathrm{mM})$ animals

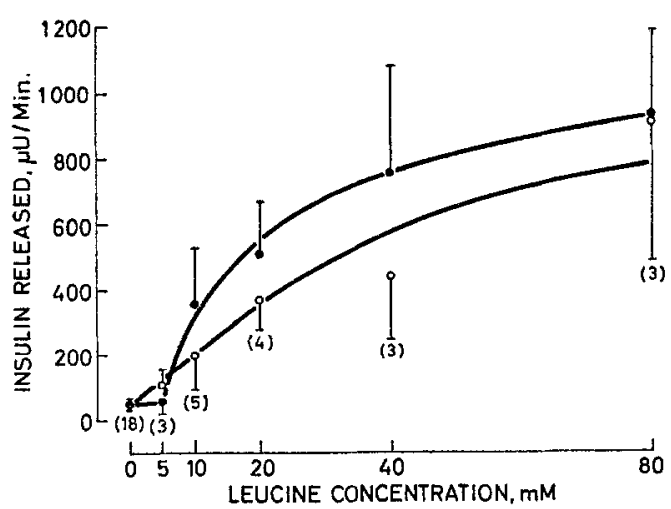

Fig. 2. Dose-dependency of leucine induced insulin release during the first $(0-10 \mathrm{~min}, 0-0)$ and second $(10-$ $40 \mathrm{~min}$, phase of release. Mean values + SEM for the number of experiments shown in brackets insulin secretory response (Fig. 2). In the second secretory phase the dependency of the hormone release on leucine concentration was characterized by a sigmoidal curve. Biphasic secretion due to leucine has also been described by Basabe et al. [13].

A remarkable phenomenon was observed when the pancreas was stimulated twice. The second stimulatory period was started after 20 min of perfusion with control medium. The second stimulation caused an insulin output that was much greater than that observed during the first stimulation. We will refer to this phenomenon as "priming" in analogy with a similar and previous described effect of glucose $[14-16]$.

b) The Influence of Glucose on Leucine-Induced Insulin Release. In the presence of a substimulatory concentration of glucose $(3 \mathrm{mM})$, leucine (10 and $20 \mathrm{mM}$ ) provoled secretion kinetics comparable to 
those induced by equimolar concentrations of leucine alone (Fig. 1). However, in the presence of $3 \mathrm{mM}$ glucose the effect of leucine was significantly greater in both phases and was almost identical to that produced by equimolar glucose (Fig. 3). Obviously, $3 \mathrm{mM}$ glucose changed the beta cell sensitivity to leucine, with $20 \mathrm{mM}$ glucose plus $20 \mathrm{mM}$ leucine (Fig. 4). These data may suggest that leucine had no influence on the beta cell sensitivity for glucose. Comparable results were published by Levin et al. [17] using arginine and glucose. The most striking feature was that the amount of insulin released upon stimulation with

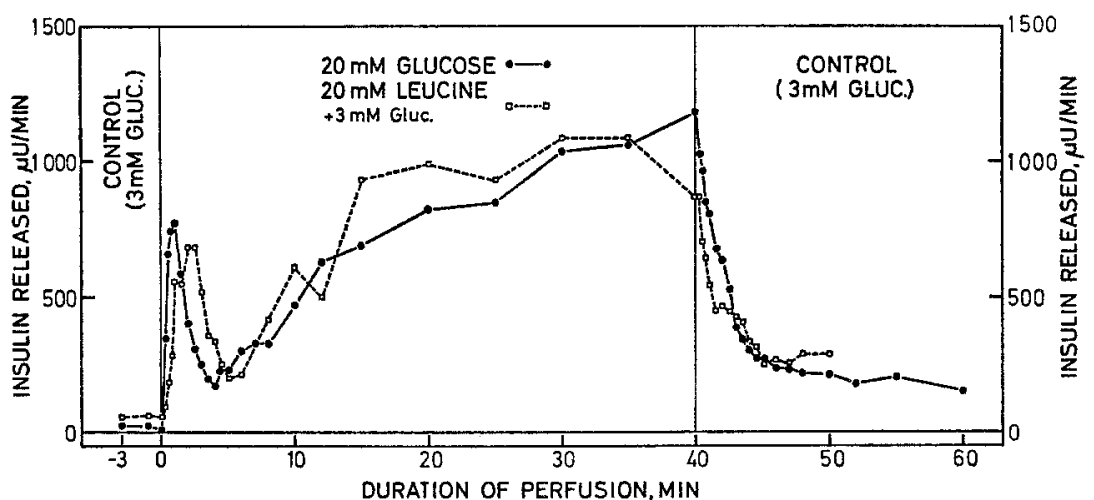

Fig. 3. Comparison of insulin secretory profiles, induced by equimolar concentrations of glucose and leucine in the presence of $3 \mathrm{mM}$ glucose. Mean values for 5 (glucose) and 4 (leucine) animals

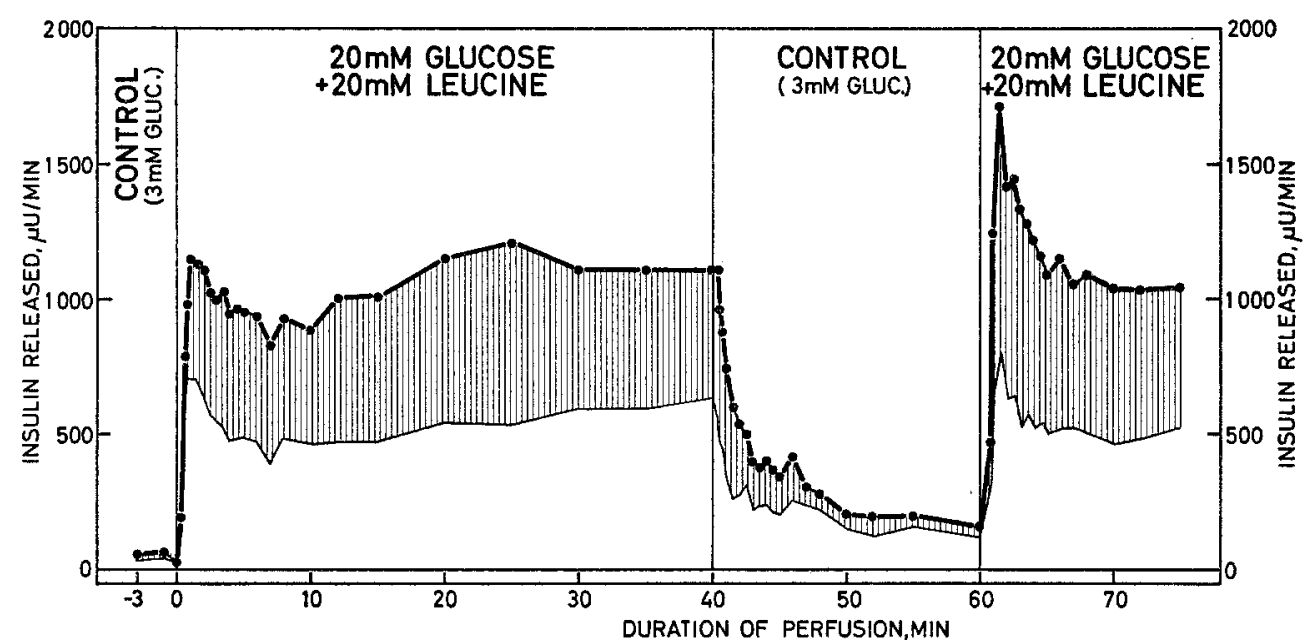

Fig. 4. Insulin secretory profile induced by simultaneous perfusion of leucine (20 mM) and glucose $(20 \mathrm{mM})$. In the control period $3 \mathrm{mM}$ glucose was present. Mean values \pm SEM for 3 animals

leading to a potentiation of the leucine stimulation. The stimulation of the beta cell with $20 \mathrm{mM}$ glucose plus 10 or $20 \mathrm{mM}$ leucine also resulted in biphasic secretion profiles (Fig. 4, shown for $20 \mathrm{mM}$ leucine). When one compares the kinetic pattern induced by leucine plus $3 \mathrm{mM}$ glucose with that of leucine plus $20 \mathrm{mM}$ glucose, it is obvious, that the high glucose concentrations had no significant additional effect. No priming was noted upon restimulation with $20 \mathrm{mM}$ leucine plus $20 \mathrm{mM}$ glucose.

c) Influence of Preperfusion with Leucine on the Subsequent Response to Glucose and Leucine. Superimposing $20 \mathrm{mM}$ glucose on a $20 \mathrm{mM}$ leucine stimulation led to a significant enhancement of insulin secretion in a biphasic manner (Fig. 5). However the total amount of insulin released was not larger than the amount of insulin released during direct stimulation
$20 \mathrm{mM}$ leucine plus $20 \mathrm{mM}$ glucose was not greater than with $20 \mathrm{mM}$ leucine plus $3 \mathrm{mM}$ glucose (Fig. 3).

Preperfusion of $20 \mathrm{mM}$ leucine followed by $40 \mathrm{mM}$ leucine resulted in a moderate further enhancement of secretion (not shown).

\section{Phenylalanine-Induced Insulin Release}

In the absence of glucose, phenylalanine (10 and $20 \mathrm{mM}$ ) did not provoke significant insulin secretion (Fig. 6). When a substimulatory level of glucose (3 mM) was present, a variable concentration independent and delayed monophasic increase of insulin release was noted (Fig. 6). Neither with nor without $3 \mathrm{mM}$ glucose could a priming effect be observed upon restimulation with phenylalanine. The removal of phenylalanine led to a marked and, up to $20 \mathrm{mM}$ 


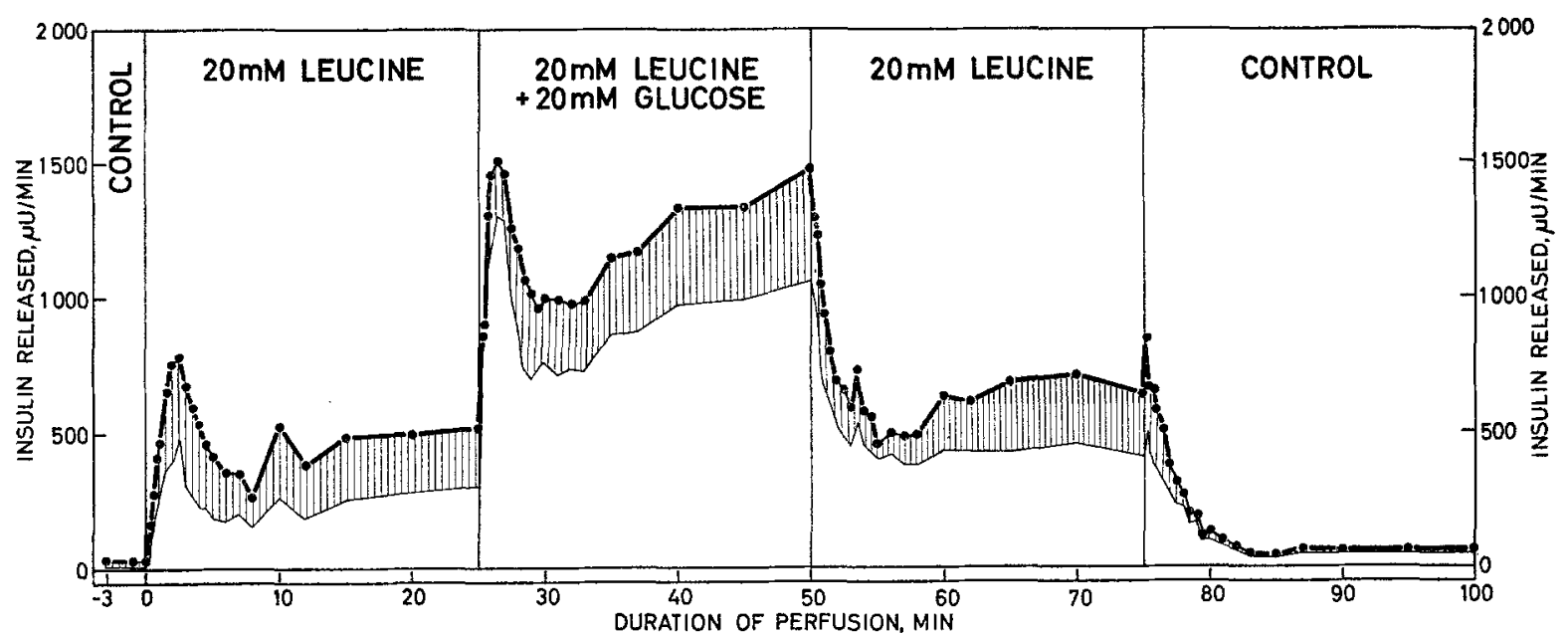

Fig. 5. Insulin secretory profile induced by sequential perfusion of leucine superimposed by glucose. In the control period glucose was omitted. Mean values \pm SEM for 4 animals

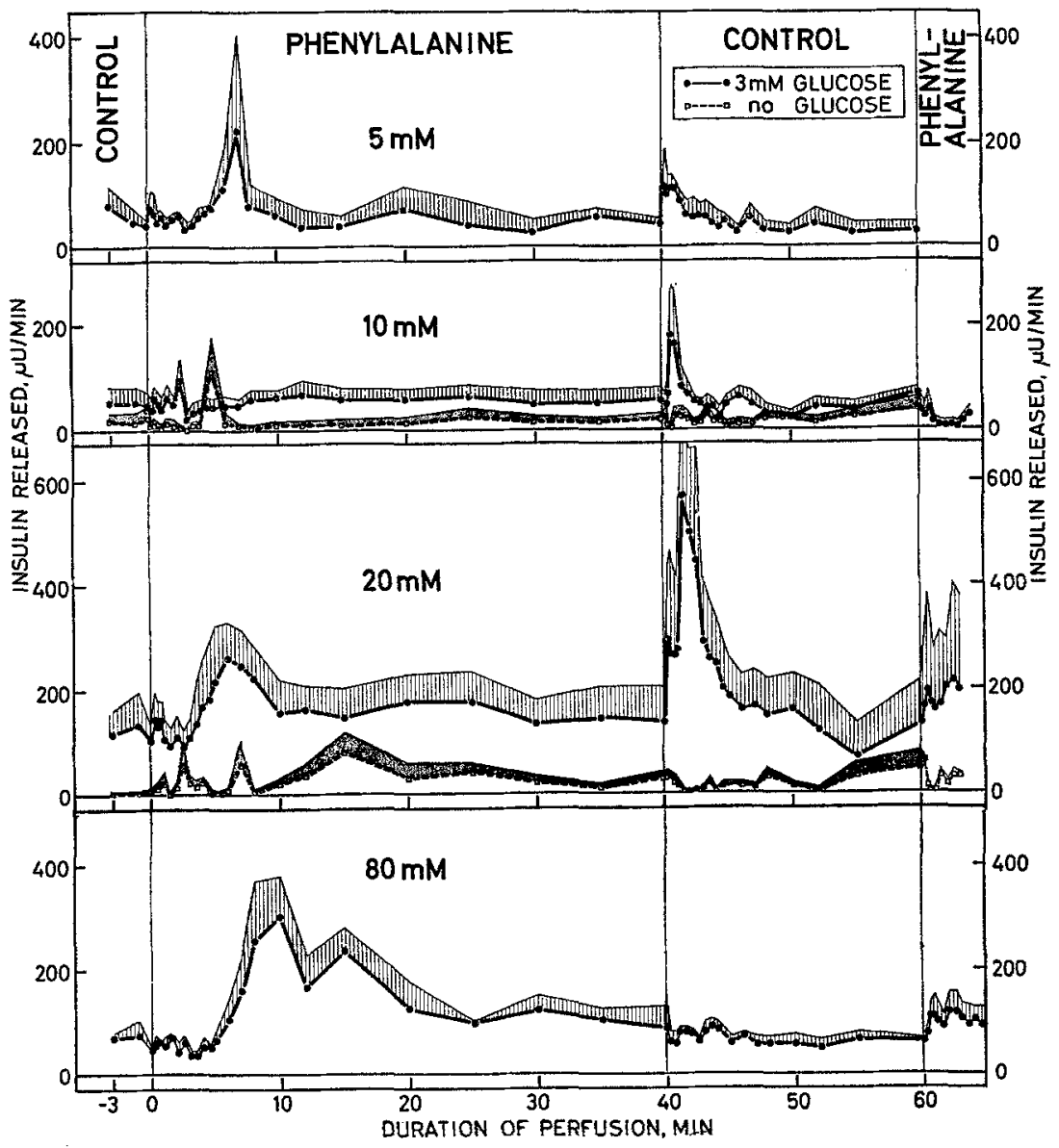

Fig. 6. Insulin secretory profiles induced by phenylalanine in the presence (- substimulatory levels of glucose. Mean values $+\mathrm{SEM}$ for $3(5 \mathrm{mM}), 5(10 \mathrm{mM}), 5(10 \mathrm{mM}+3 \mathrm{mM} \mathrm{glucose}), 3(20 \mathrm{mM})$, $5(20 \mathrm{mM}+3 \mathrm{mM}$ ghucose $)$ and $3(80 \mathrm{mM})$ animals

phenylalanine, dose-dependent enhancement of insulin release. The absence of such an "off-response" to $80 \mathrm{mM}$ phenylalanine could be due to the amino acid being toxic at this concentration.
In order to test whether in fact phenylalanine inhibited insulin release, $10 \mathrm{mM}$ phenylalanine was superimposed on a $20 \mathrm{mM}$ glucose stimulus (Fig. 7). Immediately after the addition of phenylalanine, 
inhibition of insulin release occurred. However, this inhibition was only transient and was followed by an increase in the release rate. In these experiments, the discontinuation of perfusion with phenylalanine led to a slight fall in the rate of insulin output but not to an "off-effect". could be released upon restimulation leading to the priming effect. A similar phenomenon might also occur during leucine stimulation. However one can also argue, that this hypersensitivity upon restimulation is caused by temporarily lasting membrane receptor changes due to previous receptor binding or insulin release

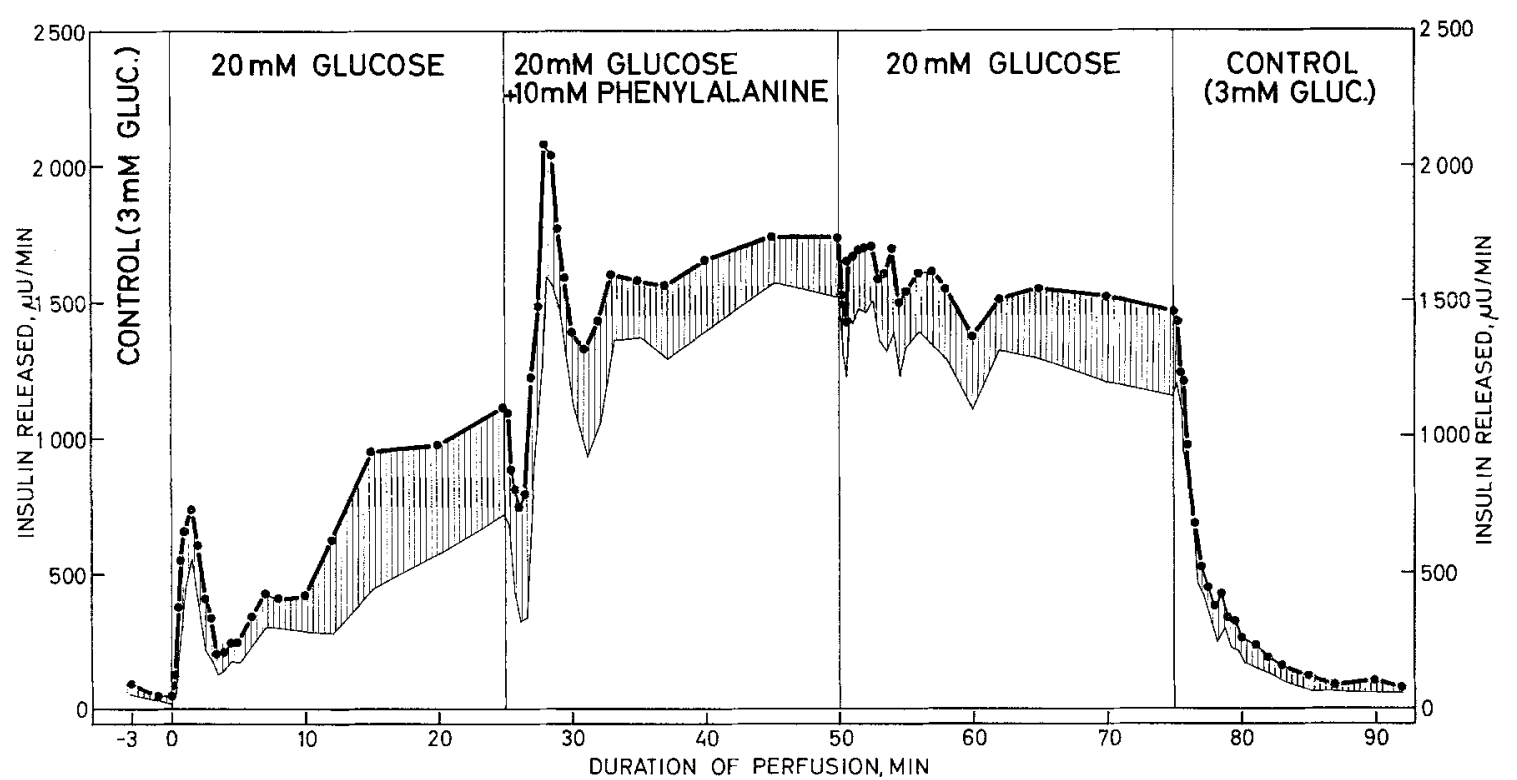

Fig. 7. Influence of phenylalanine $(10 \mathrm{mM})$ on the glucose $(20 \mathrm{mM})$ induced insulin release. Mean values $\pm S E M$ for 3 animals

\section{Discussion}

At low concentrations of leucine only a small and delayed initial phase of insulin release could be observed. Increasing concentrations of leucine not only enhanced the rapidity of onset and the rate of release during the initial phase, but also led to a second phase of secretion. Using pieces of rabbit pancreas Milner [6] found a linear relationship between the rate of insulin secretion and leucine concentration in the range $0-12.5 \mathrm{mM}$ during a $30 \mathrm{~min}$ incubation. Similarily, a linear dose-response relationship was observed in our experiments with glucose-free medium during the first phase of release $(0-10 \mathrm{~min})$ up to $20 \mathrm{mM}$ leucine. In the second phase $(10-40 \mathrm{~min})$, however, a sigmoid dose-response curve was obtained with maximum stimulation above $20 \mathrm{mM}$ leucine. Lernmark obtained similar results studying isolated islets of obese hyperglycemic mice [18].

The hyperresponsiveness of the beta cell ("priming") noted when prolonged leucine stimulation was followed by a short rest period and restimulation is not well understood. Applying a threshold distribution hypothesis for packet storage of insulin, Grodsky [15] suggested that after prolonged stimulation with high glucose a still unknown agent continues to provide additional insulin into a labile compartment in the absence of the stimulus. This "overfilled" compartment
The limitation of the hypersensitivity in time could be shown for glucose: After a rest period of forty minutes no priming could be detected (unpublished data).

The rate of insulin release due to leucine (10 and $20 \mathrm{mM}$ ) was potentiated by $3 \mathrm{mM}$ glucose. The possibility that glucose could activate leucine metabolism in the beta cell and thereby enhance the secretory response to leucine is unlikely, since Hellman et al. [9] found an inhibitory action of glucose on leucine oxidation. Moreover, maximum leucine oxidation was observed with as little as $5 \mathrm{mM}$ amino acid and the rate of oxidation of leucine, arginine and alanine did not correlate with the ability of these amino acids to induce insulin secretion. From these data it was conchuded that amino aciods do not act as insulin secretagogues by serving as fuels for the beta cell.

Although the role of glucose in connection with leucine induced insulin secretion is obscure, it is conceivable that glucose may enhance the affinity of a beta cell receptor for leucine through conformational changes of the beta cell membrane. Such an effect would be possible, if glucose and leucine receptors are located closely enough at the beta cell membrane, so that the activation of one would lead to conformational changes of the other, making it more accessible. However the only receptors for leucine that have as yet been identified in the beta cell plasma membrane are the systems $\mathrm{A}$ and $\mathrm{L}$ for transport of neutral 
amino acids $[3,19]$. It is noteworthy therefore that glucose does not affect leucine uptake by microdissected islets of obese-hyperglycemic mice [3].

Phenylalanine was not able to provoke marked insulin release in the presence or in the absence of substimulatory levels of glucose. From the fact that phenylalanine is an essential amino acid and is incorporated into the insulin molecule we conclude that it has to be transported into the beta cell. Therefore transport of an amino acid may not be sufficient for stimulating insulin release. This view was also stressed by Hellman et al. [3]. They found for example uptake of alanine [3] and D-leucine [19] into mouse islets without insulin secretion.

The dose-dependent "off-effect" after removal of phenylalanine is only demonstrable in the presence of substimulatory levels of glucose. This phenomenon seems to be specific for certain compounds (for example phenylalanine, glucosamine [20] and fatty acids [21]), and is not due to rapid changes in perfusion flow or pressure or changes in the osmotic pressure of the medium. The absence of the "off-effect" with $80 \mathrm{mM}$ phenylalanine could be due to irreversible alterations in the islets at this high concentration. It is reasonable to assume, that the rapid release which occurs as a consequence of the removal of phenylalanine is due to a de-inhibition. However it is interesting to note, that during phenylalanine perfusion no inhibition of the basal secretion rate occured. An inhibitory effect could only be demonstrated in the presence of $20 \mathrm{mM}$ glucose. At this glucose concentration the inhibitory phase was quickly overcome by a short hypersecretion. Further studies are obviously necessary to identify the site at which phenylalanine exerts its inhibitory action.

In conclusion, the data support the idea that the receptor site of transport system $L$ is not identical with the site signalling insulin release [19]. The positive or negative interactions of the two amino acids with glucose, phenomena which may not be due to metabolic events, seems to favour the concept of different receptors, which can be modified by glucose.

Acknowledgements. We wish to thank Novo Research Laboratories, Copenhagen, for the kind supply of insulin used in this study. We wish to express our appreciation. to Dr. A. Lernmark and Dr. I.-B. Täljedal, Department of Histology, University of Umea, Sweden, for their very helpful suggestions and criticism. The work was supported by the "Deutsche Forschungsgemeinschaft" SFB 51.

\section{References}

1. Lambert, A. E. B., Jeanrenaud, B., Junod, A., Renold, A. E.: II. Insulin release induced by amino and organic acids, by hormonal peptides, by cationic alterations of the medium and by other agents. Biochem. biophys. acta 184, 540-553 (1969)

2. Christensen, H.N., Hellman, B., Lernmark, A., Sehlin, J., Tager, H.S., Täljedal, J.B.: In vitro stimulation of insulin release by non-metabolizable, transport-specific amino acids. Biochem. biophys. acta 241, $341-348$ (1971)
3. Hellman, B., Sehlin, J., Täljedal, J.-B.: Uptake of alanine, arginine, and leucine by mammalian pancreatic $\beta$-cells. Endocrinology 89, $1432-1439$ (1971)

4. Floyd, J.C. jr., Fajans, S.S., Pek, S., Thiffault, C.A., Knopf, R.F., Conn, J.W.: Synergistic effect of certain amino acid pairs upon insulin secretion in man. Diabetes 19, 102-108 (1970)

5. Fajans, S.S., Floyd, J.C. jr., Conn, J.W.: Effect of amino acids and proteins on insulin secretion in man. Recent Progr. Hormone Res. 23, 617-662 (1967)

6. Milner, R.D.G.: The stimulation of insulin release by essential amino acids from rabbit pancreas in vitro. J. Endoer. 47, 347-356 (1970)

7. Edgar, P., Rabinowitz, D., Merimee, T.J.: Effects of amino acids on insulin release from excised rabbit pancreas. Endocrinology 84, 835-843 (1969)

8. Sussman, K.E., Vaughan, G.D., Timmer, R.F.: An in vitro method for studying insulin secretion in the perfused isolated rat pancreas. Metabolism 15, 466476 (1968)

9. Hellman, B., Sehlin, J., Täljedal, J.-B.: Effects of glucose and other modifiers of insulin release on the oxidative metabolism of amino acids in microdissected pancreatic islets. Biochem. J. 123, 513-521 (1971)

10. Lowry, O.H., Passonneau, J.V., Hasselberger, F.X., Schulz, D.W.: Effect of ischemia on known substrates and cofactors of the glycolytic pathway in brain. J. biol. Chem. 239, $18-30$ (1964)

11. Hales, C.N., Randle, P.J.: Immunoassay of insulin with insulin-antibody precipitate. Biochem. J. 88, $137-146(1963)$

12. Porte, D., jr., Bagdade, J. D. : Human insulin secretion: An integrated approach. Ann. Rev. Med. 21, 219-240 (1970)

13. Basabe, J.C., Lopez, N.L., Victoria, J.K., Wolff, F.W.: Insulin secretion studied in the perfused rat pancreas. I. Effect of tolbutamide, leucine and arginine; their interaction with diazoxide, and relation to glucose. Diabetes 20, $449-456$ (1971)

14. Curry, D.L.: Is there a common beta cell insulin compartment stimulated by glucose and tolbutamide. Amer. J. Physiol. 220, 319 (1971)

15. Curry, D.L.: The effect of cycloheximide and 2deoxyglucose on the diphasic pattern of insulin secretion. Acta diabet. lat. 8, 48 (1971)

16. Grodsky, G.M.: A threshold distribution hypothesis for packet storage of insulin and its mathematical modeling. J. clin. Invest. 51, $2047-2059$ (1972)

17. Levin, S.R.; Karam, J.H., Hane, S., Grodsky, G.M., Forsham, P.H.: Enhancement of arginine-induced insulin secretion in man prior administration of glucose. Diabetes 20,171-176 (1971)

18. Lernmark, A.: Specifity of leucine stimulation of insulin release. Hormones 3, 14-21 (1972)

19. Hellman, B., Sehlin, J., Täljedal, J.-B.: Transport of L-leucine and D-leucine into pancreatic $\beta$-cells with reference to the mechanisms of amino acid - induced insulin release. Biochem. biophys. acta 266, 436-443 (1972)

20. Landgraf, R., Kotler-Brajtburg, J., Matschinsky, F.M.: Kinetics of insulin release from the perfused rat pancreas caused by glucose, glucosamine and galactose. Proc. Nat. Acad. Sci., (Wash.) 68, 536-540 (1971)

21. Fertel, R.: The effect of $\alpha$-carbon substituted shortchain monocarboxylic acids on insulin release. The penetration of hexoses into the islets of Langerhans. Thesis, Washington University, St. Louis, Mo. (1972)

Dr. R. Landgraf

Ir. Medizinische Klinik

der Universität München

D-8000 München

Ziemssenstraße 1 